\title{
INFLUENCE OF DIFFERENT EXTRACTION METHODS ON PHYSIOCHEMICAL AND BIOLOGICAL PROPERTIES OF $\beta$-GLUCAN FROM INDIAN BARLEY VARIETIES
}

\begin{tabular}{|c|c|}
\hline \multicolumn{2}{|c|}{ Neha Mishra $^{1}$, Neetu Mishra ${ }^{2 \bowtie,}$ Pragya Mishra ${ }^{3}$} \\
\hline $\begin{array}{r}{ }^{1} \text { Sam Higginbottom } U \\
{ }_{2}^{2} \text { Department } \\
{ }^{3} \text { DDU Kaushal Kendrc } \\
\text { https://doi.org/10.343 }\end{array}$ & $\begin{array}{l}\text { f Agriculture, Technology and Sciences, Prayagraj, India, } 21100 \\
\text { cience, University of Allahabad, Prayagraj, India, } 211002 \\
\text { Banaras Hindu University, Varanasi-221005, Uttar Pradesh, Indi } \\
{ }_{\text {neetum1976@gmail.com }} \\
\text { t/2020.12.1.3 }\end{array}$ \\
\hline Article history: & $\overline{\text { ABSTRACT }}$ \\
\hline $\begin{array}{l}\text { Received: } \\
\text { 24 March } 2019 \\
\text { Accepted: } \\
\text { 10 January } 2020 \\
\end{array}$ & $\begin{array}{l}\text { Currently barley has received renewed interest especially due to its high } \\
\text { content of glucans. Since the glucan content vary greatly with genotype, four } \\
\text { hull less barley variety (K-551, RD-2794, RD-2035 and RD-2552) } \\
\text { commonly cultivated in northern plains of India were chosen for study. In }\end{array}$ \\
\hline $\begin{array}{l}\text { Keywords: } \\
\text { Barley; } \\
\text { Biological Properties; } \\
\text { Extraction; } \\
\text { Physiochemical properties; } \\
\text { Glucan. }\end{array}$ & $\begin{array}{l}\text { this study we isolate } \beta \text {-glucan from different barley cultivars by four } \\
\text { different methods includes alkali, acidic, hot water and enzymatic methods. } \\
\text { Different extraction methods have significant effect on yield, recovery, } \\
\text { functional and biological properties. Highest gum yield ( } 4.85 \%) \text { was found } \\
\text { in samples that were extracted by hot water treatment in all barley cultivars. } \\
\text { Although the highest recovery were achieved by enzymatic method }(86.7 \%) \\
\text { followed by hot water extraction method }(85.2 \%) \text {. Among all cultivars, RD- } \\
2552 \text { identified to have highest glucan content }(4.57 \%) \text { and therefore } \\
\text { selected to evaluate the effect of different extraction methods on functional } \\
\text { and biological properties. Highest water binding capacity ( } 3.82 \mathrm{~g} / \mathrm{g}) \text { and } \\
\text { foaming capacity (1.65g/g) was exhibited by hot water extraction method } \\
\text { where as enzymatic method result in highest viscosity ( } 49.1 \mathrm{cP}) \text {. The } \\
\text { biological properties were determined in term of antioxidant and } \\
\text { antimicrobial activities. In this study found extraction method have no } \\
\text { significant effect on the antioxidant activity but have significant effect on } \\
\text { antimicrobial activity. Among all method, enzymatic extraction methods } \\
\text { give highest recovery of glucan and exhibit highest antioxidant and } \\
\text { antimicrobial activity. }\end{array}$ \\
\hline
\end{tabular}

\section{Introduction}

Barley (Hordeum vulgare L.) is an important cereal grain throughout the world, belonging to the family Poaceae and the genus Hordeum (Mekonnon et al. 2015).In India, it is commonly grown in northern plains such as states of UP, Rajasthan, MP, Bihar, Punjab, Haryana, HP and $\mathrm{J} \& \mathrm{~K}$. They are rich source of protein, soluble fiber, vitamin, minerals and also exhibit positive physiological effects (Marwat et al. 2012).Even though, $90 \%$ of barley commonly used as feeds for animals, malting and brewing (Stanca et al. 2016). Barley is one of the ancient crops and had been consumed as food since centaury however recently its functional importance has recognized due to its high nutritional value especially because of its high glucan content. $\beta$ glucans are the polymers of glucose units linked by $\beta-1,3$ and/or $\beta-1,4$ linkage with or without side branches $\beta(1,6) / \beta(1,2)$ glycosidic linkage (Barsanti et al 2011). Commercially $\beta$ - glucan isolated from different sources such as oats, barley, mushrooms and some microorganisms.

Beta glucans derived from cereals are the long linear chain of glucose composed of cellatriosyl and cellatetraosyl units linked by $\beta$ 
(1- 3$)$ and $\beta(1-4)$ linkages in a ratio of $3: 7$. Beta glucan constitutes $1 \%$ of wheat grains, $3-7 \%$ of oats and $5-11 \%$ of barley (Skendi et al 2003). In barley, $\beta$-glucan concentrated in the cell walls of the endosperm and aleurone layer which varies with species. $\beta$-glucan has received considerable attention due to their health benefits includes promotion of colonic health, lowering the risk of constipation and colorectal cancer, reduction of serum cholesterol and regulation of blood glucose levels (Lattimer and Haub 2010; Das et al 2012).

Agencies such as Food and Drug Administration,1997 (FDA) and the scientific panel of European Food Safety Authority, 2010 (EFSA) has acknowledged the nutritional claims of $\beta$-glucan for lowering the blood glucose and cholesterol levels of individuals and recommended the intake of 3 gram of $\beta$-glucan per day for its health benefits.

In addition, $\beta$-glucans exhibits specific physiochemical properties such as viscosity, swelling capacity, foaming ability and stability that increase its potential for utilization as functional ingredients in food industry (Ahmad et al 2012).

It have been documented that the genetic background of barley is more important than environmental conditions for determining the $\beta$ glucan content of the grain. Along with $\beta$ glucan, its cell wall also contains enzymes, starch, protein, fats and minerals which interfere in the extraction of glucan.

For extraction of $\beta$-glucan various traditional to modified methods such as ultrasound-assisted extraction (UAE), response surface methodology (RSM), microwaveassisted extraction (MAE), and accelerated solvent extraction (ASE) have been developed.

Traditional methods such as alkali, acidic, hot water and enzymatic methods has been found to be simple, economical and proven to be successful in lowering blood cholesterol and glucose.

These methods have significant effect on the yield and functional properties of $\beta$-glucan which have technological role in food industry. The aim of the study was to evaluate the best extraction method on the basis of their yield, recovery and functional and biological properties. Since the glucan content vary greatly with genotype, four hull-less barley variety (K551, RD-2794, RD-2552, RD-2035) commonly cultivated in northern plains of India were chosen for study. Four different procedures include alkali, acidic, hot water and enzymatic methods were employed to isolate the glucan.

Then the effects of different extraction methods on yield, purity, functional and biological properties of $\beta$-glucan were analyzed in order to obtain the best method of extraction.

FDA recognized barley as functional food ingredient exhibits the positive physiological effect but there are limited studies on the effect of extraction methods on its activity. Therefore, in present study antioxidant activity of different gum pellets were also analyzed.

\section{Materials and Methods}

\subsection{Procurement and Sample Preparation}

Among the different varieties of barley, four hull-less barley variety commonly cultivated in northern plain of India (K-551, RD-2794, RD2552, RD-2035) were procured from Agro Food Industry, Jabalpur, India.

Whole barley was milled in a high-speed electric mill and sieved by a mesh size of $20 \mathrm{~mm}$ and stored for further analysis.

\subsection{Extraction and Purification of $\beta$-glucan}

There are four extraction methods were used for extraction of $\beta$-glucan from whole barley grain. Four methods includes as alkaline extraction that employ $\mathrm{NaOH}$, acidic extraction in which citric acid was used; hot water extraction and the fourth method was enzymatic extraction accomplish by aamylase enzyme.

Before extraction, $50 \mathrm{~g}$ of flour was suspended in $500 \mathrm{ml}$ of aqueous ethanol $(80 \%$, $\mathrm{v} / \mathrm{v}$ ) and stirred under reflux for $6 \mathrm{~h}$ at $85{ }^{\circ} \mathrm{C}$ to inactivate endogenous $\beta$-glucanases and to remove most of the lipids. A schematic outline of the extraction protocol is presented in figure 1. 


\section{Alkaline Extraction}

$100 \mathrm{~g}$ Flour

Refluxing with $80 \%$ Ethanol for 6 hours

Mixing the Flour with $1 \mathrm{M} \mathrm{NaOH}$ in 1:7 ratio

Mixing on hot plate with Magnetic Stirrer for $90 \mathrm{Min}$ at $55^{\circ} \mathrm{C}$

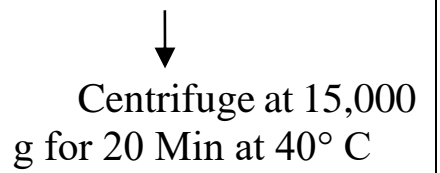

$\mathrm{g}$ for 20 Min at $40^{\circ} \mathrm{C}$

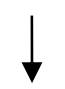

Supernatant taken \& mixed with $1 \mathrm{M} \mathrm{NaOH}$ in $1: 3$ ratio

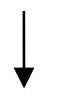

Centrifuged at $18,000 \mathrm{~g}$ for $20 \mathrm{~min}$ at $40^{\circ} \mathrm{C}$

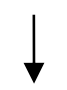

Supernatant adjusted at PH 7 with Citric Acid

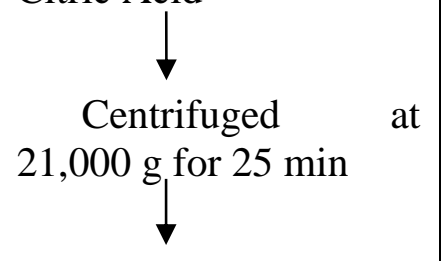

Acidic Extraction

Hot
Extraction

$100 \mathrm{~g}$ Flour

Refluxing with $80 \%$ Ethanol for 6 hours

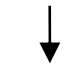

Mixing the Flour with $1 \mathrm{M}$ Citric Acid in $1: 7$ ratio

Mixing on hot plate with Magnetic Stirrer for $90 \mathrm{Min}$ at $55^{\circ} \mathrm{C}$

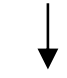

Centrifuge at 15,000 $\mathrm{g}$ for $20 \mathrm{Min}$ at $40^{\circ} \mathrm{C}$

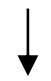

Supernatant taken \& mixed with $1 \mathrm{M}$ Citric Acid in 1:3 ratio

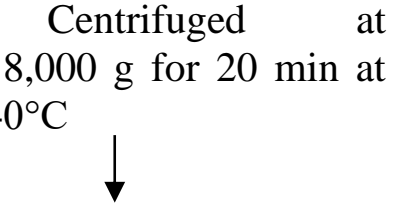

Supernatant was Neutralized at $\mathrm{PH} 7$ with $\mathrm{NaOH}$

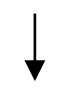

Centrifuged $21,000 \mathrm{~g}$ for $25 \mathrm{~min}$<smiles>C[Tl]</smiles>

Refluxing with $80 \%$ Ethanol for 6 hours

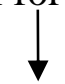

Mixing the Flour with water in 1:10 ratio<smiles>[3H]I</smiles>

High speed stirring on hot plate with Magnetic Stirrer for 90 Min at $55^{\circ} \mathrm{C}$

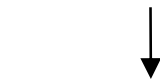

Centrifuge at 15,000 $\mathrm{g}$ for $20 \mathrm{Min}$ at $40^{\circ} \mathrm{C}$

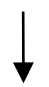

Supernatant

adjusted at PH 8.5 with sodium bicarbonate and stirred on hot plate for $30 \mathrm{~min}$ at $55^{\circ} \mathrm{C}$

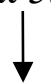

Centrifuged

$18,000 \mathrm{~g}$ for $20 \mathrm{~min}$ at $40^{\circ} \mathrm{C}$

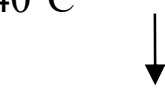

Supernatant

adjusted at PH 7 with Citric Acid

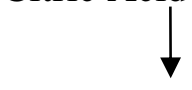

Centrifuged $21,000 \mathrm{~g}$ for $25 \mathrm{~min}$

at
$100 \mathrm{~g}$ Flour

Refluxing with $80 \%$ Ethanol for 6 hours

Treated with heat stable Alpha amylase at $40{ }^{\circ} \mathrm{C}$

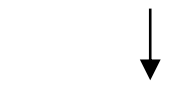

Centrifuge at 15,000 $\mathrm{g}$ for $20 \mathrm{Min}$ at $40^{\circ} \mathrm{C}$

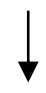

Supernatant was treated with Protease Enzyme at $37^{\circ} \mathrm{C}$ and incubated for 3 hours

Centrifuged at $21,000 \mathrm{~g}$ for $25 \mathrm{~min}$ at $4^{\circ} \mathrm{C}$

Mix Supernatant + Ethanol (80\%) 1:1 and hold for $20 \mathrm{~min}$

Centrifuged at 4000 g at $4^{\circ} \mathrm{C}$ 


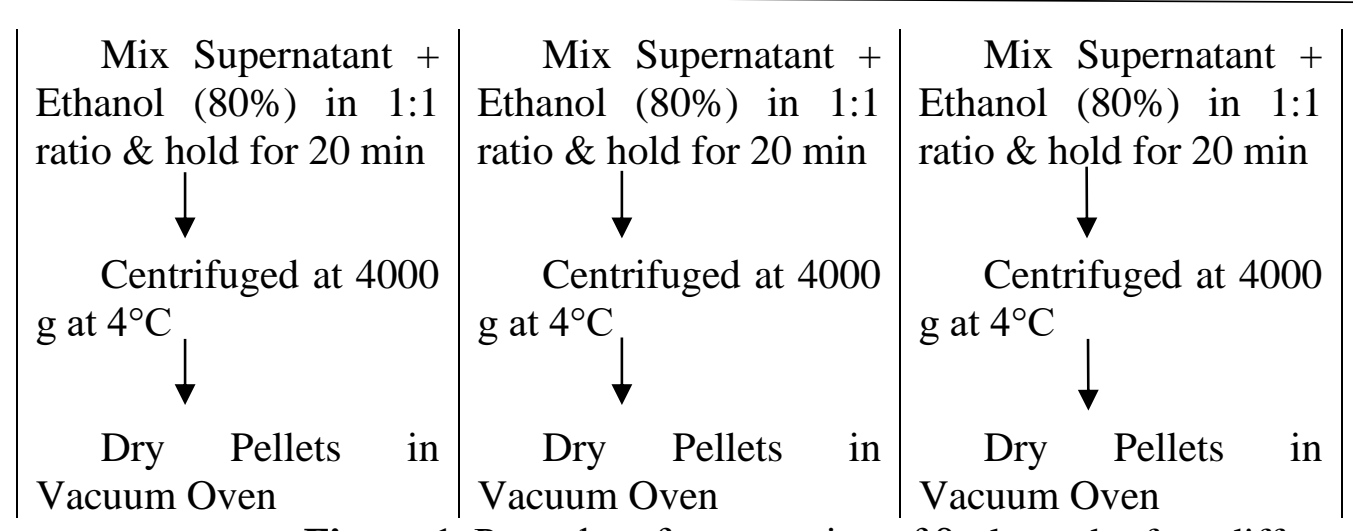

Figure 1. Procedure for extraction of $\beta$-glucan by four different methods

\subsection{Estimation of $\beta$-glucan}

The $\beta$-glucan content was determined using the $\beta$-glucan enzymatic assay kit (Megazyme International Ireland Ltd, Wicklow, Ireland). It determines the recovery of $\beta$-glucan from barley flour by different extraction methods.

\subsection{Proximate Composition}

The proximate composition includes moisture, protein, fat, starch and total dietary fiber of flour and gum pellets were determined according to the approved method of American Association of Cereal Chemists Method (AACC, 2003). Protein content of the $\beta$-glucan isolates was estimated by the method of Lowry et al.1967.

\subsection{Physiochemical properties}

The functional properties of $\beta$-glucan such as water binding capacity, swelling capacity, viscosity and foaming capacity were studied.

\subsubsection{Water binding capacity}

The water binding capacity (WBC) of samples was measured by the modified method described by Wong \& Cheung (2005). Twenty millilitre of distilled water was added into a centrifuge tube containing $200 \mathrm{mg} \beta$-glucan. After which it was placed in a shaker at $25{ }^{\circ} \mathrm{C}$ for $12 \mathrm{~h}$, the tubes were centrifuged at $14000 \mathrm{~g}$ for $30 \mathrm{~min}$ at $25{ }^{\circ} \mathrm{C}$. The supernatant (unbound water) was discarded, and the amount of water held in the hydrated sample was determined by heating the pre-weighed pellet in a hot air oven for $2 \mathrm{~h}$ at $120^{\circ} \mathrm{C}$. The WBC of each sample was expressed as the weight of water held by $1.0 \mathrm{~g}$ of $\beta$-glucan sample.

\subsubsection{Viscosity measurement}

For viscosity measurements, $1 \%(\mathrm{w} / \mathrm{v}$, as is basis) dispersion of $\beta$-glucan gum in deionised water was prepared by heating mixtures at 100 ${ }^{0} \mathrm{C}$ for $10 \mathrm{~min}$ followed by stirring on magnetic stirrer at $30{ }^{\circ} \mathrm{C}$ for $2 \mathrm{~h}$ and adjusting $\mathrm{pH}$ at 7 . Viscosity was measured using a Rion viscometer (Rion Co., Ltd, Boston, MA, USA).

\subsubsection{Swelling power}

The swelling power was determined according to the method described by Okaka and Potter (1977). In $100 \mathrm{ml}$ graduated cylinders, samples were filled to $10 \mathrm{ml}$ mark and then distilled water was added up to $50 \mathrm{ml}$. Mix suspension thoroughly and mark the volume occupied by the sample after the $18 \mathrm{~h}$.

\subsubsection{Foaming capacity}

The foaming capacity was studied by following the method of Temelli (1997) with slight modification. $2.5 \mathrm{~g}$ of gum pellets were dissolved in $100 \mathrm{ml}$ distilled water. The resulting solution was mixed vigorously for 2 min using a hand-held food mixer at high speed in a stainless steel bowl with straight sides and volumes were recorded before and after whipping. The percentage volume increase (which serves as index of foam capacity) was calculated according to the following equation:

Foaming capacity $(\%)=$ (volume after whipping - volume before whipping) $\times 100$ (Volume before whipping) (Eq.1) 


\subsubsection{Color}

The color value for $\beta$-glucan pellets were measure by using $L^{*} a^{*} b^{*}$ color space with color tech, USA.

\subsection{Biological activity}

\subsubsection{Antimicrobial activity}

The antimicrobial activity was determined by well diffusion method. The bacterial culture obtained from the Department of Microbiology, Chandigarh, India. $100 \mu 1$ of glucan pellets $(1 \mathrm{mg} / \mathrm{ml})$ extracted from different methods was added into wells. The plates were incubated for $24 \mathrm{~h}$ at $37^{\circ} \mathrm{C}$ and zone of inhibition was measured by zone inhibitory scale.

\subsubsection{DPPH radical scavenging activity}

The radical scavenging activity of algal extracts was measured according to the method of Brand-Williams et al (1995) with slight modification. Briefly, fresh stock solution of DPPH (4.3 mg DPPH in $3.3 \mathrm{~mL}$ absolute methanol) was prepared and stored at $4{ }^{\circ} \mathrm{C}$ until use in the experiment. Concentration of $0.1 \mathrm{ml}$ of glucan extract $(0.5-2 \mathrm{w} / \mathrm{v} \%)$ was added to 150 $\mu \mathrm{DPPH}$ solution and make up the volume to $3 \mathrm{ml}$ with pure methanol. The reaction mixture was incubated in the dark for 15 minutes at room temperature, and the absorbance was measured at $517 \mathrm{~nm}$ was measured using UV-VISION spectrophotometer (UV-2450, Shmadzu, Japan). The radical scavenging activity of samples was expressed as the percentage discoloration of DPPH solution by using the following equation:

Free radical scavenging activity $(\%)=$ $\left\{\left(\mathrm{A}_{\text {blank }}-\mathrm{A}_{\text {sample }}\right) / \mathrm{A}_{\text {blank }}\right\} \times 100 \%$ (Eq. 2$)$

where A sample was the absorbance with sample and Ablank was the absorbance without sample. Ascorbic acid was used as positive control.

\subsubsection{Chelating ability on ferrous ions}

Chelating ability was determined according to the method of Sutharut, (2012). $0.5 \mathrm{ml}$ of glucan extract $(0.5-2 \mathrm{w} / \mathrm{v} \%)$ was mixed with 1.6 $\mathrm{ml}$ of $80 \%$ methanol and $50 \mu \mathrm{l}$ ferrous chloride. The reaction was initiated by the addition of 0.1 $\mathrm{ml}$ of $5 \mathrm{mM}$ ferrozine. After $10 \mathrm{~min}$ at room temperature, the absorbance of the mixture was determined at $562 \mathrm{~nm}$ against the blank. Blank was the solution with all reagents but without extract. A lower absorbance indicates a higher chelating ability. EDTA was used for reference standard.

\subsection{Statistical analysis}

All experiments were done in triplicates and data represent the means $\pm \mathrm{SD}$. The means were analyzed by one- way ANOVA and significant differences between treatments were tested using Duncan's multiple range test (DMRT). $P$ values $\leq 0.05$ were considered significant. Statistical analyses were carried out using Statistical Package for the Social Sciences (SPSS) 16.0.

\section{Results and discussions}

\subsection{Screening of Barley Variety}

\subsubsection{Nutritional composition of barley} varieties

Table 1 summarized the chemical composition of different variety of barley ranges 10.5-12.9\% protein, $2.88-3.25 \%$ fat, $59.1-64.5 \%$ starch, $17-21.3 \%$, total dietary fiber, and $\beta$ glucan content varied from 3.57-4.87\%. The chemical composition of barley varies with environmental region and species (Zhu et al 2017). In consistent to previous study this study also that the major components of barley are starch, dietary fibre, and crude protein (Asare et al 2011;Biel et al 2013; Bleidere et al 2015 Rodehutscord et al. 2016).In all four Indian barley cultivar glucan present in good quantity varies from $3.57-4.87 \%$. In support of this study, Irakli et al (2004) had observed $\beta$-glucan in range to $3.91 \%-5.93 \%$ in the 6 barley varieties and Papageorgiou (2005) reported that the $\beta$-glucan content in barley and oat cultivars ranged $2.5 \%$ to $5.4 \%$ and $2.1 \%$ to $3.9 \%$, respectively. Proximate composition of barley flour indicates that barley cultivar RD-2552 has highest nutritional value in term of ash $(2.58 \%)$, protein $(12.9 \%)$, fiber $(21.3 \%)$ and $\beta$-glucan (4.57\%). 
Table 1. Nutritional composition of different Indian barley varieties

\begin{tabular}{|c|c|c|c|c|}
\hline Barley variety & DWR-28 & RD-2503 & RD-2035 & RD-2552 \\
\hline Moisture (\%) & $8.12 \pm 0.9^{\mathrm{a}}$ & $8.65 \pm 0.97^{\mathrm{b}}$ & $9.51 \pm 1.32^{\mathrm{c}}$ & $9.43 \pm 1.2^{\mathrm{d}}$ \\
\hline Ash (\%) & $2.2 \pm 0.12^{\mathrm{a}}$ & $2.32 \pm 0.143^{\mathrm{ab}}$ & $2.46 \pm 0.16^{\mathrm{b}}$ & $2.58 \pm 0.09^{\mathrm{c}}$ \\
\hline Protein (\%) & $10.5 \pm 1.07^{\mathrm{a}}$ & $11.7 \pm 1.1^{\mathrm{b}}$ & $12.4 \pm 0.94^{\mathrm{c}}$ & $12.9 \pm 1.14^{\mathrm{c}}$ \\
\hline Fat (\%) & $2.88 \pm 0.21^{\mathrm{a}}$ & $3.17 \pm 0.17^{\mathrm{b}}$ & $3.25 \pm 0.13^{\mathrm{bc}}$ & $2.99 \pm 0.17^{\mathrm{ab}}$ \\
\hline Starch (\%) & $59.1 \pm 2.5^{\mathrm{a}}$ & $61.97 \pm 2.7^{\mathrm{b}}$ & $62.34 \pm 1.9^{\mathrm{b}}$ & $64.52 \pm 2.3^{\mathrm{c}}$ \\
\hline TDF (\%) & $17.05 \pm 2.5^{\mathrm{a}}$ & $17.95 \pm 2.9^{\mathrm{b}}$ & $19.25 \pm 3.1^{\mathrm{c}}$ & $21.35 \pm 2.8^{\mathrm{d}}$ \\
\hline Glucan(\%) & $3.57 \pm 0.19^{\mathrm{a}}$ & $3.73 \pm 0.17^{\mathrm{a}}$ & $4.27 \pm 0.21^{\mathrm{b}}$ & $4.873 \pm 0.2^{\mathrm{c}}$ \\
\hline
\end{tabular}

Values are averages of triplicates (Mean \pm SD). Mean with different superscript letters in the same column are significant different $(p<0.05)$

\subsubsection{Gum Yield and recovery of $\beta$ glucan in different barley varieties}

The result of present studies revealed that different extraction methods were found to have a significant $(\mathrm{P} \leq 0.05)$ effect on gum yield and recovery of all barley variety. Figure 2 a elicited the yield of gum product (wt. of gum $/ 100 \mathrm{~g}$ flour) ranges from 3.1 to $5.8 \%$ in different barley variety by different extraction methods. In this support Vizhi et al (2014) and Ahmed et al (2009) documented the gum yield $4.65 \%$ and $5.4 \%$ respectively. Highest gum yield achieved by hot water method $(5.85 \%)$ followed by alkaline method of extraction (5.1\%). In consistent of previous research lower yield of $\beta$ glucan $(3.62 \%)$ obtained under acidic extraction (Ahmed 2009, Ahmed 2010; Babu 2015). Several researchers were reported that along $\beta$ glucan small amounts of fat, protein, starch, pentosans and mineral (ash) matter also present in flour. They were extracted along with glucan as impurities and reduced the recovery of $\beta$ - glucan. Consequently, in order to determine the efficiency of various extraction methods recovery of $\beta$-glucan has calculated. $\beta$-Glucan recovery represents the $\%$ ratio of weight of $\beta$ glucan in extracted gum product to the weight of $\beta$-glucan in $100 \mathrm{~g}$ flour. Figure $2 \mathrm{~b}$ elicited that different methods of extraction have significant effect on glucan recovery ranges from $74.8 \%$ $86.7 \%$ in different barley cultivars. Enzymatic extraction followed by hot water extraction procedure results in highest recovery (\%) in all barley variety. Among all cultivars RD-2552 attained highest recovery $(86.7 \%)$ in enzymatic extraction method followed by $85.2 \%$ recovery attained in water method and lowest recovery $(81.2 \%)$ obtained by alkaline method using $1 \mathrm{M}$ $\mathrm{NaOH}$. Similarly $85 \%-92 \%$ of recovery in water extraction had been observed by previous studies (Irakli et al 2004; Skendi et al 2003; Papageorgiou et al 2005, Ahmed 2009). This study indicated that among all cultivars RD- 
2552 identified to have highest glucan content and selected for further analysis.

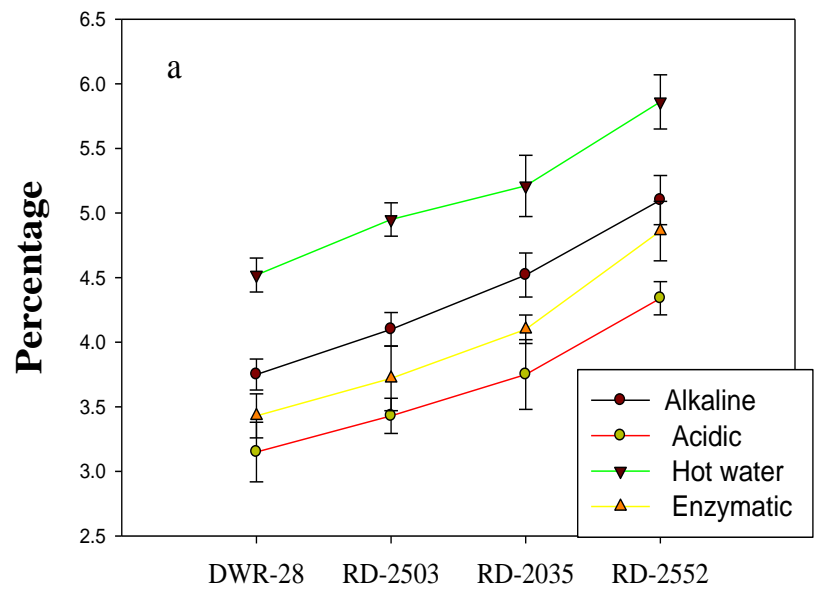

Gum Yield (\%)

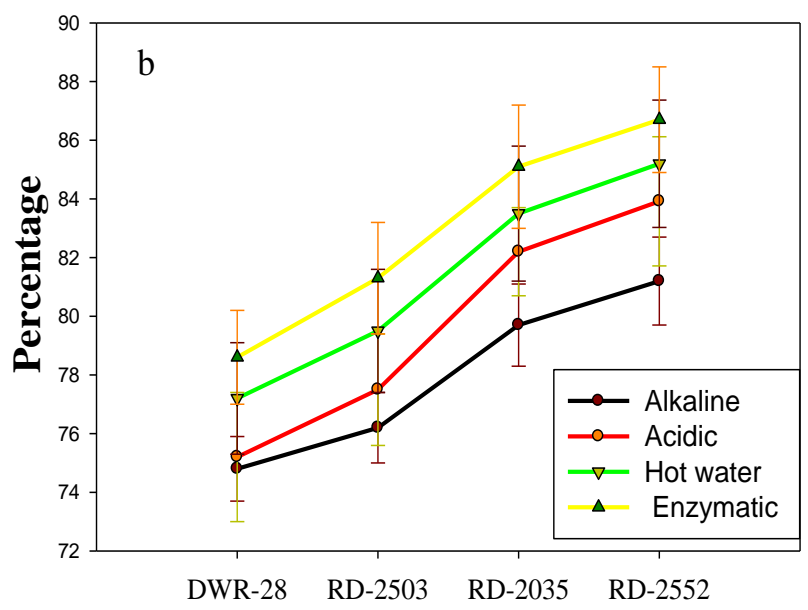

Glucan recovery $(\%)$

Figure 2. Yield and Recovery of $\beta$-glucan in different barley varieties

3.2. Effect of Different Extraction Methods on Selected Barley Beta Glucan

\subsubsection{Chemical composition of $\beta$-glucan pellets}

The chemical compositions of gum extracted from barley RD-2552 by different methods were illustrated in figure 3 . All the methods have significant effect $(p \leq 0.05)$ on the composition of gums includes starch, protein, lipid, fiber. These were the impurities extracted along with $\beta$ glucan and may affects its physiochemical properties and its utilization as functional ingredient in various food system (Wood, 2004; Burkus \& Temelli, 2005). Among all constituent protein and starch were the major impurities vary substantially from $5.72 \%$ to $6.23 \%$ and $3.59 \%$ to $3.9 \%$ respectively. Highest protein content $(6.23 \%)$ were observed in water extraction procedure shows its inefficiency to remove protein. Although, acidic treatments were found efficient to remove protein as added acid meets the isoelectric point of protein which support its precipitation and removal. This work found that substantial amount of glucan could be extracted by alkaline method but this gum have considerable starch $(3.9 \%)$ and protein $(6.1 \%)$ impurities resulting in impure glucan products (Cui et al 2000; Wei et al 2006; Li et al 2006).
Like oats, in barley glucan compartmentalized in starch- protein matrix and therefore appeared as major impurities during extraction of $\beta$ glucan. Symons and Brennan (2004) compared extraction procedures showing that extraction with thermostable alpha-amylase yielded the purest $\beta$-glucan fraction. Lowest content of starch $(3.59 \%)$ and protein $(5.72 \%)$ were observed when enzymatic method was adopted. This was because enzymatic procedure were most efficient to remove impurities such as starch and proteins from extracted $\beta$-glucans due to the alpha amylase and proteinase enzyme facilitates the precipitation of starch and protein respectively (Mikkelsen,et al 2012). Although the highest content of fat (1.18\%) was observed in enzymatic procedure this may undergo oxidative degradation and produces bitter flavor during processing and storage. The ash (mineral) content of glucan pellets varies from $1.23 \%$ to $1.65 \%$ with higher content in alkaline $(1.65 \%)$ followed by enzymatic $(1.55 \%)$ procedure. Different extraction methods significantly $(p<$ 0.05 ) affect the total dietary fiber(TDF), soluble dietary fiber (SDF) and insoluble dietary fiber (IDF). It is well documented that high fiber reduces the risk of heart disease, diabetes, colorectal cancer, obesity and inflammation. In 
this study gum extracted by enzymatic methods exhibit highest glucan content $(88.18 \%)$ was comparable to previous study. The higher amounts of dietary fiber in extracted $\beta$-glucan gum makes it suitable for many industrial applications such as preparing bread, cookies and other cereal-based pasta produc

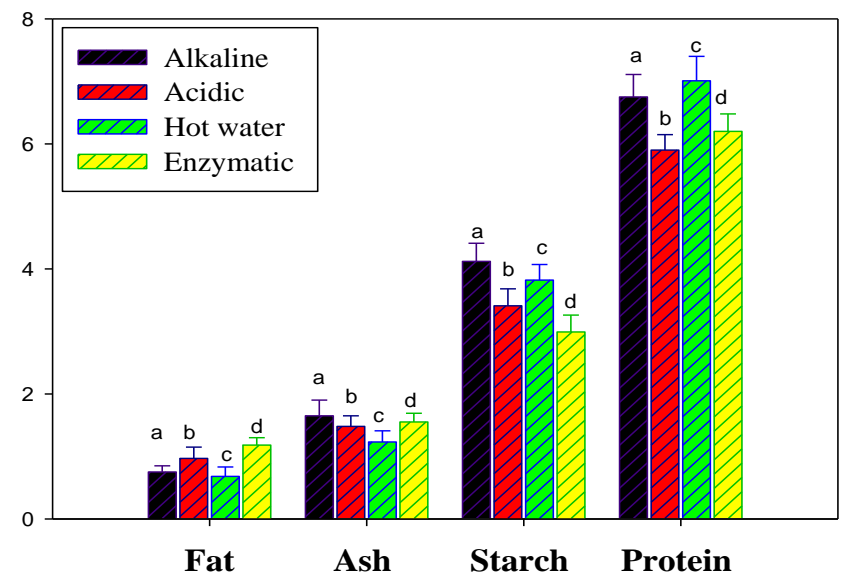

Figure 3.Chemical Analysis of $\beta$-glucan pellets extracted from different methods

\subsubsection{Physiochemical Properties}

\subsubsection{Water binding capacity (WBC)}

The functional properties are important determinants of $\beta$-glucan to be applied in food industry for formulation of different food products. Water binding capacity (WBC) is defined as the amount of water retained by a known weight of samples (Robertson et al 2000). Hot water extraction method exhibited the highest WBC (3.82 g/g dry weight) followed by alkaline (3.17 g/g dry weight) and acidic fractions $(2.89 \mathrm{~g} / \mathrm{g}$ dry weight). The water binding properties increases its potential for various food products such as jam, jellies, sauces and cheese as it put off the syneresis problem. In addition high water holding capacity also helps to control moisture migration and ice crystal formation; therefore increases thaw stability (Kulp and Joseph, 2014). Previous study reported that $\beta$-glucan well suited for the replacement of thickeners and to improve the consistency of food products such as drinks, dressing, and fermented dairy products due to its water binding capacity. Table 3 illustrated the significant positive correlation of WHC with $\operatorname{starch}(\mathrm{r}=0.77, p \leq 0.05)$ and protein content $(\mathrm{r}=0.99, p \leq 0.05)$ and negative correlation with fat $(\mathrm{r}=-0.95, p \leq 0.05)$.

\subsubsection{Swelling capacity}

Different extraction methods have no significant effect on swelling capacity on $\beta$ glucan . Swelling capacity of glucan varies between $8.2-7.98 \mathrm{~g} / \mathrm{g}$ in the following order: Alkaline $>$ Acidic $>$ Hot water $>$ Enzymatic. The Pearson correlation of coefficient shows the positive correlation $(r=0.99, p<0.05)$ of starch with swelling capacity as starch absorb water. Proteins may lower the swelling power by being embedded in the starch granules forming a stiff matrix that limits the access of water into the starch granule and showed negative correlation with swelling power $(r=-0.30)$.

\subsubsection{Viscosity}

Enzymatic method exhibits highest viscosity $(50.1 \mathrm{cP})$ but lowest WBC $(2.32 \mathrm{~g} / \mathrm{g})$, swelling capacity $(7.98 \mathrm{~g} / \mathrm{g})$ and foaming capacity $(1.15 \mathrm{~g} / \mathrm{g})$. Similarly, Panahi et al. (2007) reported that the viscosity of beta-glucan was highly preserved by the enzymatic method, which improved postprandial glycemic control when incorporated into a fiber drink. It have been reported that biological properties of glucan related to its ability to form viscous solution. Alkaline and acidic extraction methods reduced the viscosity of the extracted betaglucan gum, because extreme $\mathrm{pH}$ can cause an unfavorable effect on the molecular structure, 
especially on the beta- $(1,3)$ linkages which leads to the depolymerisation of linear structure of $\beta$ glucan. The positive correlation was experienced between viscosity and soluble fiber $(\mathrm{r}=0.921, p \leq 0.05)$ as presented in table 3 .

\subsubsection{Foaming capacity $(F C)$}

Foaming capacity (FC) varied significantly $(P \leq 0.05)$ among the flours. Foams are used to improve texture, consistency and appearance of foods (Akubor 2007). FC was calculated as \% increase in volume of protein dispersion upon mixing. Highest foaming capacity $(1.65 \mathrm{~g} / \mathrm{g})$ was attained in water extraction procedure may be due to its high protein content which form a continuous cohesive film that trapped more air to develop more foam. This is further supported by the result of Pearson correlation coefficient $(\mathrm{r}=0.67)$ shows protein supports foaming ability. High foaming capacity and stability is desirable characteristic in making cakes and batters although the lowest foaming capacity exhibit in enzymatic method. Table 3 elicited the negative correlation $(r=-0.99)$ between foaming capacity and fat content which is reasoned as fat interferes with the foaming properties

\subsubsection{Color}

The color characteristics $\left(\mathrm{L}^{*}, \mathrm{a}^{*}, \mathrm{~b}^{*}\right)$ of glucan pellets extracted from different methods are presented in table 2. The significant differences were observed between the different color parameters in all glucan pellets. The $\mathrm{L}^{*}$ values for different glucan varied 69.2 to 75.5 indicates the lightness of product. Glucan extracted by hot water methods possessed highest $L^{*}(75.5)$ value and lowest $a^{*}(6.3)$ value. The high $\mathrm{L}^{*}$ value had a technologically advantage for the addition in various food product as it may increase product acceptance without affecting the base color. Correlation study (Table 4) indicates a highly positive correlation between $\mathrm{L}^{*}$ value and soluble fibre $(\mathrm{r}=0.94, p \leq 0.05)$. Highest $\mathrm{b}^{*}$ value (29.4) attained by alkaline methods reflects the yellowness of glucans that increase its suitability for soups, dips and sauces. The positive correlation observed between $b^{*}$ value and starch content $(r=0.85, p \leq 0.05)$ as it has been seen that the variation in $b^{*}$ value among samples may be attributed to the amount of carbohydrate (Jamin and Flores 1998).

Table 2.Effects of different extraction methods on physiochemical properties

\begin{tabular}{|c|c|c|c|c|c|c|c|}
\hline $\begin{array}{c}\text { Extraction } \\
\text { Methods }\end{array}$ & $\begin{array}{c}\text { WBC } \\
(\mathbf{g} / \mathbf{g})\end{array}$ & $\begin{array}{c}\text { Swelling } \\
\text { capacity } \\
(\mathbf{g} / \mathbf{g})\end{array}$ & $\begin{array}{c}\text { Viscosity } \\
(\mathbf{c P})\end{array}$ & $\begin{array}{c}\text { Foaming } \\
\text { capacity } \\
(\mathbf{g} / \mathbf{g})\end{array}$ & $\mathbf{L}^{*}$ & $\mathbf{a}^{*}$ & $\mathbf{b}^{*}$ \\
\hline Alkaline & $3.17^{\mathrm{a}}$ & $8.12^{\mathrm{ab}}$ & $37.12^{\mathrm{a}}$ & $1.52^{\mathrm{a}}$ & $69.2^{\mathrm{a}}$ & $11.7^{\mathrm{a}}$ & $29.4^{\mathrm{a}}$ \\
\hline Acidic & $2.89^{\mathrm{b}}$ & $\mathbf{8 . 2}^{\mathrm{a}}$ & $45.7^{\mathrm{b}}$ & $1.35^{\mathrm{b}}$ & $70.3^{\mathrm{b}}$ & $8.9^{\mathrm{b}}$ & $23.6^{\mathrm{b}}$ \\
\hline Hot Water & $\mathbf{3 . 8 2}^{\mathrm{c}}$ & $8.05^{\mathrm{b}}$ & $48.6^{\mathrm{c}}$ & $\mathbf{1 . 6 5}^{\mathrm{c}}$ & $\mathbf{7 5 . 5}^{\mathrm{c}}$ & $6.3^{\mathrm{c}}$ & $19.8^{\mathrm{c}}$ \\
\hline Enzymatic & $2.32^{\mathrm{d}}$ & $7.98^{\mathrm{c}}$ & $\mathbf{5 0 . 1}^{\mathrm{d}}$ & $1.15^{\mathrm{d}}$ & $72.8^{\mathrm{d}}$ & $7.5^{\mathrm{d}}$ & $15.7^{\mathrm{d}}$ \\
\hline
\end{tabular}

Values are averages of triplicates (Mean \pm SD). Mean with different superscript letters in the same column are significant different $(p<0.05)$

Table 3. Correlation among different parameters

\begin{tabular}{|c|c|c|c|c|c|c|c|}
\hline & WBC & SC & VISCO & FC & $\mathbf{L}^{*}$ & $\mathbf{a}^{*}$ & $\mathbf{b}^{*}$ \\
\hline Starch & 0.24 & 0.99 & -0.99 & 0.38 & -0.79 & 0.97 & 0.85 \\
\hline Protein & 0.75 & -0.30 & -0.18 & 0.67 & -0.12 & -0.58 & -0.16 \\
\hline Fat & -0.95 & -0.58 & 0.48 & -0.99 & 0.84 & -0.28 & -0.59 \\
\hline IDF & -0.299 & 0.792 & -0.853 & -0.122 & -0.98 & 0.98 & 0.98 \\
\hline SDF & 0.131 & -0.877 & 0.921 & -0.051 & 0.94 & -0.89 & -1.00 \\
\hline
\end{tabular}




\subsubsection{Anti-oxidant activity}

$\beta$-glucans are the promising compounds having wide health promoting activity due to its biological activities. In present study the antioxidant activities were determined using different assays like DPPH (2, 2-diphenyl-1picryl-hydrazyl), and metal chelating ability. In this study found that extraction method have no significant effect on the antioxidant activity of glucan. Free radicals are the major contributor degenerative diseases such as, diabetes mellitus cardiovascular disease, cancer and immune system. The radical scavenging activity was determined by DPPH assay at different concentrations is shown in Fig. 4a. Among all extraction procedures, gum extracted by enzymatic method exhibits highest free radical

a. radical scavenging ability

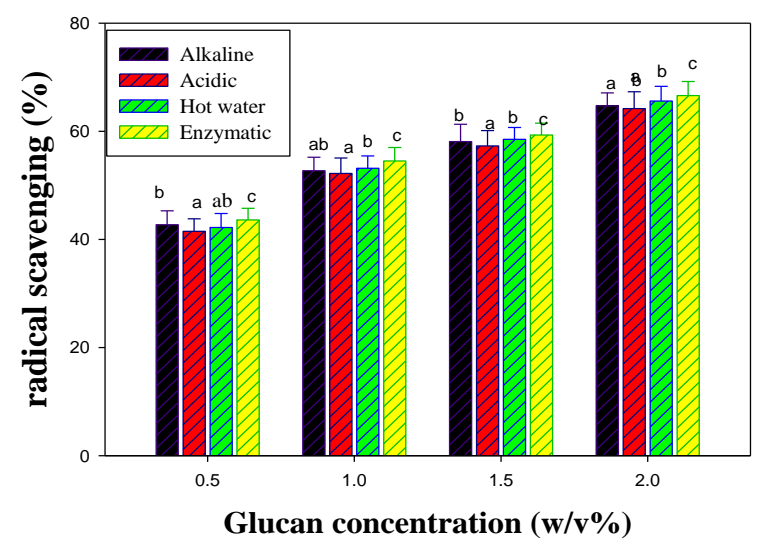

scavenging activity (43.3\%-66.6\%). No significant difference was observed in radical scavenging activity of alkaline and hot water extraction method. Transition metal ions, especially iron can stimulate lipid peroxidation and thereby perpetuate chain reaction. Chelating activity measures the ability of an antioxidant to deactivate the metals and prevents lipid peroxidation. Metal chelating activity at different concentration of gum extracted by different procedure varies from $35.9 \%-61.7 \%$ (figure $4 \mathrm{~b}$ ). The present result coincides with the study conducted by Kyoko kofuji et al (2012) reported that beta-glucan extracted by various methods have high scavenging activity and metal chelating activity.

Figure 4. Antioxidant activity of $\beta$-glucan pellets extracted from different methods

\subsubsection{Antimicrobial activity}

In present study the antibacterial activity of glucan pellets was tested against both Gramnegative (Escherichia coli,Pseudomonas, Shigella) and Gram-positive bacteria (Streptococcus aureus) by well diffusion method. The antibacterial activity was determined by measuring zone of inhibition against standard (streptomycin), elicited in Table 4. The significant effect of extraction methods on antibacterial activity of $\beta$-glucan was observed. Among all the methods, maximum zone of inhibition was observed by enzymatic extracted glucan followed by hot water extracted glucan. The result revealed that all extract have good inhibition activity against tested bacteria. The maximum zone of inhibition was observed against $S$ aureus $(23 \mathrm{~mm})$ followed by $E \operatorname{coli}(21 \mathrm{~mm})$ and minimium zone of inhibition was observed against Shigella $(10 \mathrm{~mm})$ followed by psedumonas $(13 \mathrm{~mm})$. The antibacterial activity was explained due to interaction of polycations of glucan cell membrane to the negatively charged bacterial surface. This interaction alters the membrane permeability and thereby inhibiting the growth. No study was found that explain the effect of extraction methods on antibacterial activity. 
Table 4. Antibacterial activity of glucan extracted by different methods

\begin{tabular}{|c|c|c|c|c|}
\hline $\begin{array}{c}\text { Extraction } \\
\text { Methods }\end{array}$ & $\begin{array}{c}\text { Staphylococcus } \\
\text { aureus }\end{array}$ & Pseudomonas & Shigella & E coli \\
\hline Alkaline & $19^{\mathrm{a}}$ & $13^{\mathrm{b}}$ & $9^{\mathrm{c}}$ & $16^{\mathrm{d}}$ \\
\hline Acidic & $20^{\mathrm{a}}$ & $15^{\mathrm{b}}$ & $11^{\mathrm{c}}$ & $17^{\mathrm{d}}$ \\
\hline Hot Water & $21^{\mathrm{a}}$ & $17^{\mathrm{b}}$ & $14^{\mathrm{c}}$ & $19^{\mathrm{d}}$ \\
\hline Enzymatic & $23^{\mathrm{a}}$ & $19^{\mathrm{b}}$ & $15^{\mathrm{c}}$ & $21^{\mathrm{d}}$ \\
\hline
\end{tabular}

Values are averages of triplicates (Mean \pm SD). Mean with different superscript letters in the same column are significant different $(p<0.05 \%)$

\section{Conclusions}

Various extraction procedures have been employed to extract the $\beta$-glucans from barley cultivars native of Northern plains of India. Barley variety RD-2552 found to have high nutritional value with high glucan content. The result of present study found that highest yield was attained by hot water extraction method whereas highest recovery and highest biological activity was achieved by enzymatic method followed by hot water extraction method. Enzymatic extraction method is found to be the best method of extraction on the basis of glucan recovery, functional and biological properties.

\section{References}

AACC, (2003). Approved Methods of American Association of Cereal Chemists. St Paul: The American Association of Cereal Chemists, Inc.

Ahmed A, Anjum FM, Zahoor T, Nawaz H, Ahmed Z. (2009). Physicochemical and functional properties of barley $\beta$-glucan as affected by different extraction procedures. International Journal of Food Science and Technology, 44,181-7.

Ahmad A, Anjum FM, Zahoor T, Nawaz H, Ahmed Z,(2010). Extraction and characterization of $\beta$-glucan from oat for industrial utilization. International Journal of biological macromolecules, 46(3), 304-9. Ahmad, A., Munir, B., Abrar, M., Bashir, S., Adnan, M. and Tabassum, T., (2012). Perspective of $\beta$-glucan as functional ingredient for food industry. Journal of Nutrition \& Food Sciences, 2(2), 133.
Akubor, P., (2007). Chemical and functional properties of modified and unmodified cassava and sweet potato starches. Journal of Food Science and Technology-Mysore, 44(3), 260-263.

Asare, E.K., Jaiswal, S., Maley, J., Båga, M., Sammynaiken, R., Rossnagel, B.G. and Chibbar, R.N., (2011). Barley grain constituents, starch composition, and structure affect starch in vitro enzymatic hydrolysis. Journal of Agricultural and Food Chemistry, 59(9) ,4743-4754.

Babu, R., (2015). Green Extraction Techniques, Structural Analysis and Antioxidant Activites of Á-Glucan Present in Oats Lekshmi. International Journal of Latest Trends in Engineering and Technology,5(4).

Barsanti, L., Passarelli, V., Evangelista, V., Frassanito, A.M. and Gualtieri, P., (2011). Chemistry, physico-chemistry and applications linked to biological activities of $\beta$-glucans. Natural product reports, 28(3), 457-466.

Biel, W. and Jacyno, E., (2013). Chemical composition and nutritive value of spring hulled barley varieties. Bulgarian Journal of Agricultural Science, 19(4), 721727.

Bleidere, M., Zute, S., Brunava, L., Bobere, N., Jākobsone I., (2013). Yield and grain quality of hulless spring barley in field trials under different nitrogen management conditions. Proceedings of the Latvian Academy of Science. Section B, 67(3), 229-235.

Brand-Williams, W., Cuvelier, M.E. and Berset, C.L.W.T. (1995). Use of a free radical method to evaluate antioxidant activity. 
LWT-Food science and Technology, 28(1), 25-30.

Burkus, Z. and Temelli, F., (2005). Rheological properties of barley $\beta$-glucan. Carbohydrate polymers, 59(4), 459-465.

Cui, S.W. and Wang, Q., (2009). Cell wall polysaccharides in cereals: chemical structures and functional properties. Structural Chemistry, 20(2), 291-297.

Das, A., Raychaudhuri, U., Chakraborty, R., 2012. Cereal based functional food of Indian subcontinent: a review. Journal of food science and technology, 49(6), 665-72.

European Food Safety Authority (2010). Scientific Opinion on the Substantiation of a Health Claim related to Oat Beta-Glucan and Lowering Blood Cholesterol and Reduced Risk of (Coronary) Heart Disease pursuant to Article 14 of Regulation (EC) No 1924/2006. EFSA Journal. 8.

FDA, (1997). Food labeling: health claims, oats and coronary heart diseases. Federal Register, 62, 3584-3681.

Irakli, M., Biliaderis, C.G., Izydorczyk, M.S., Papadoyannis, I.N. (2004). Isolation, structural features and rheological properties of water-extractable $\beta$-glucans from different Greek barley cultivars. Journal of the science of food and agriculture, 84, $1170-8$.

Jamin, F.F. and Flores, R.A. (1998). Effect of Additional Separation and Grinding on the Chemical and Physical Properties of Selected Corn Dry-Milled Streams. Cereal Chemistry, 75(1), 166-170.

Kulp, K. and Joseph, G. Ponte, Jr. (2014). Hand book of Cereals Science \& Technology. Second Edition.

Kofuji, K., Aoki, A., Tsubaki, K., Konishi, M., Isobe, T. and Murata, Y., (2012). Antioxidant activity of $\beta$-glucan. ISRN pharmaceutics.

Lattimer, J.M., Haub, M.D., (2010). Effects of dietary fiber and its components on metabolic health. Nutrients 2,1266-89.
Lowry, O.H., Rosebrough, N.J., Farr, A.L., and Randall, R.J., (1951). Protein measurement with the Folin phenol reagent. Journal of Biological Chemistry. 193, 265-275.

Mekonnon, B., Lakew, B., Dessalegn, T., (2015). Morphological diversity and association of traits in ethiopian food barley (Hordeum vulgare 1.) landraces in relation to regions of origin and altitudes. Journal of Plant Breeding and Crop Science. 28, 7(2), 44-54.

Marwat, S. K., Hashimi, M., Khan, K. U., Khan, M. A., Shoaib, M., Fazal-ur-Rehman. (2012). Barley (Hordeum vulgare L.) A Prophetic Food Mentioned in Ahadith and its Ethnobotanical Importance. American. Eurasian Journal of Agricultural and Environmental Sciences. 12(7), 835-841.

Mikkelsen, M.S., (2012). Comparison of functional and nutritional characteristics of barley and oat mixed linkage $\beta$ glucans (Doctoral dissertation, Department of Food Science, University of Copenhagen).

Okaka, J.C., Potter, N.N.,(1977). Functional and storage properties of cow pea-wheat flour blends in bread making. Journal of Food Science,42,828-833.

Panahi, S., Ezatagha, A., Temelli, F., Vasanthan, T. and Vuksan, V., (2007). $\beta$-Glucan from two sources of oat concentrates affect postprandial glycemia in relation to the level of viscosity. Journal of the American College of Nutrition, 26(6), 639-644.

Papageorgiou, M., Lakhdara, N., Lazaridou, A., Biliaderis, C.G., Izydorczyk, M.S. (2005). Water extractable $(1 / 3,1 / 4)-\beta$-D-glucans from barley and oats: an intervarietal study on their structural features and rheological behavior. Journal of Cereal Science, 42, 213-24.

Robertson, J.A., de Monredon, F.D., Dysseler, P., Guillon, F., Amado, R. and Thibault, J.F., (2000). Hydration properties of dietary fibre and resistant starch: a European collaborative study. LWT-Food Science and Technology, 33(2), 72-79. 
Rodehutscord, M., Rückert, C., Maurer, H.P., Schenkel, H., Schipprack, W., Bach Knudsen, K.E., Schollenberger, M., Laux, M., Eklund, M., Siegert, W. and Mosenthin, R., (2016). Variation in chemical composition and physical characteristics of cereal grains from different genotypes. Archives of animal nutrition, 70(2), 87-107.

Skendi, A., Biliaderis, C.G., Lazaridou, A., Izydorczyk, M.S. (2003). Structure and rheological properties of water soluble $\beta$ glucans from oat cultivars of Avena sativa and Avena bysantina. Journal of Cereal Science, 38, 15-31.

Stanca, A.M., Gianinetti, A., Rizza, F., Terzi, V. (2016). Barley: an overview of a versatile cereal grain with many food and feed uses. In: Wrigley CW, Corke H, Seetharaman K, Faubion J, editors. Encyclopedia of food grains. 2nd ed. Oxford: Elsevier. p 147-52.

Sutharut, J. and Sudarat, J. (2012). Total anthocyanin content and antioxidant activity of germinated colored rice. International Food Research Journal, 19(1).

Symons, L.J., Brennan, C.S. (2004). The effect of barley 13-glucan fibre fractions on starch gelatinisation and pasting characteristics. Journal of Food Science, 69, 257-261.

Temelli. F.(1997). Extraction and functional properties of barley $\beta$-glucan as affected by temperature and $\mathrm{pH}$. Journal of Food Science, 62(11), 92-1201.

Vizhi, V.K., Many, J.N. (2014). Study on estimation, extraction and analysis of barley beta-glucan. International Journal of Scientific Research, 3(10), 1480-4.

Wong, K.H. \& Cheung, P.C.K. (2005). Dietary fibers from mushroom sclerotia: preparation and physicochemical and functional properties. Journal of Agriculture and Food Chemistry, 53, 9395-9400.

Wei, L., Steve, W.C., Yukio, K. (2006). Extraction, fractionation, structural and physical characterization of wheat b-Dglucans. Carbohydrate Polymers, 63, 408416.
Zhu, F. (2017). Barley Starch: Composition, Structure, Properties, and Modifications. Comprehensive Reviews in Food Science and Food Safety, 16(4), 558-579. 